\title{
Cardiac autoantibodies in dilated cardiomyopathy become undetectable with disease progression
}

Alida L P Caforio, Jonathan H Goldman, Mirza K Baig, Aldwyn J Haven, Luciano Dalla Libera, Philip J Keeling, William J McKenna

\begin{abstract}
Objective-To determine the relation of cardiac autoantibody and disease status in a consecutive series of patients with dilated cardiomyopathy by prospective antibody testing at diagnosis and at follow up.

Methods-Antibody status was assessed by indirect immunofluorescence in 110 patients with dilated cardiomyopathy $(85$ male, mean (SD) age 44 (13) years) at diagnosis and at follow up (mean (SD) 14 (12) months); in 57 of them cardiac specific anti- $\alpha$ myosin antibody titres were also measured by an enzyme-linked immunosorbent assay (ELISA). Patients underwent complete evaluation at diagnosis and clinical and non-invasive assessment at follow up, including exercise testing with maximal oxygen consumption measurements.
\end{abstract}

Results-The frequency of cardiac specific antibodies by immunofluorescence was lower at follow up than at diagnosis (28 (25\%) v $11(10 \%), P=0 \cdot 002)$. Mean (SEM) anti- $\alpha$ myosin antibody titres at follow up were also lower than at diagnosis $(0.24(0.02) v 0.30(0.02), P=0.038) ; 24 \%$ of patients at diagnosis and $14 \%$ at follow up had an abnormal ELISA result. None of the patients who were negative by immunofluorescence or ELISA at diagnosis became positive at follow up. Presence of antibody at diagnosis was associated with milder symptoms and greater exercise capacity at follow up and persistence of antibody at follow up was associated with stable disease and milder symptoms at diagnosis.

Conclusions-Cardiac specific autoantibodies in dilated cardiomyopathy become undetectable with disease progression; this is a recognised feature of other autoimmune conditions, such as type 1 diabetes. Detection of these antibodies at diagnosis and at follow up may provide a non-invasive marker of early dilated cardiomyopathy.

(Heart 1997;77:62-67)

Keywords: idiopathic dilated cardiomyopathy; cardiac specific antibodies; autoimmune disease; anti-myosin antibodies

Dilated cardiomyopathy is a chronic heart muscle disease of unknown aetiology. ${ }^{12}$ The finding of circulating autoantibodies to various cardiac autoantigens provides evidence for autoimmunity in a subset of patients. ${ }^{3-11}$ Indirect immunofluorescence ${ }^{8}$ or an $\alpha$-myosin specific enzyme-linked immunosorbent assay (ELISA) ${ }^{12}$ detected organ and disease specific cardiac autoantibodies at diagnosis in about a third of patients with dilated cardiomyopathy. Detection of these antibodies in 15-20\% of the symptom-free relatives of such patients is further evidence for autoimmune involvement and suggests that autoimmunity may account for a even greater proportion of cases. ${ }^{1213}$

The autoimmune features found in dilated cardiomyopathy closely resemble insulindependent diabetes mellitus. ${ }^{13}{ }^{14}$ Islet cell antibody markers are found in most patients with type 1 diabetes at the onset of symptoms but are detected in only $30-40 \%$ of those with long-standing diabetes. ${ }^{15}{ }^{16}$ Most patients with dilated cardiomyopathy may be antibody negative at diagnosis because of a decline in antibody titres with disease progression.

To determine the relation of antibody and disease status we performed prospective antibody testing in patients with dilated cardiomyopathy at diagnosis and at follow up.

\section{Patients and methods}

\section{STUDY TRIAL DESIGN}

We studied 110 consecutive patients with dilated cardiomyopathy (mean (SD) age 44 (13), 85 male) who presented to a tertiary referral centre for heart failure and arrhythmia treatment. All patients underwent clinical assessment and cardiac antibody testing by immunofluorescence at diagnosis and at their first follow up visit (mean (SD) 14 (12), range 1 to 74 months after diagnosis); in addition, in 57 patients anti- $\alpha$ myosin antibody titres were measured by ELISA at diagnosis and follow up. The ELISA measurements were performed on the same sera used for antibody detection by immunofluorescence but investigators were blinded to the immunofluorescence results. The 57 patients in whom ELISA was performed were unselected: they were those in whom enough serum was available for testing. All immunological tests were performed without knowledge of the clinical data. The study was approved by our institutional review committee and all patients gave informed consent.

PROTOCOL FOR CLINICAL EVALUATION OF PATIENTS WITH IDIOPATHIC DILATED CARDIOMYOPATHY AT DIAGNOSIS AND FOLLOW UP

The diagnosis of dilated cardiomyopathy was based on the demonstration of a dilated and 
poorly contracting left ventricle, according to present recommendations. ${ }^{12}$ Exclusion criteria were: $\geqslant 50 \%$ obstruction of one or more coronary arteries, myocarditis, specific heart muscle disease, sustained systemic arterial hypertension ( $\geqslant 150 / 90 \mathrm{~mm} \mathrm{Hg}$ ), isolated right ventricular dilatation, and valve or pericardial disease. Patients who had a history of chronic excess alcohol consumption, as previously defined, ${ }^{17}$ were excluded.

All 110 study patients underwent clinical and non-invasive assessment, including a 12 lead electrocardiogram, chest radiography, and $M$ mode and cross sectional transthoracic Doppler echocardiography; 48 hour ambulatory electrocardiographic monitoring was performed in 83 patients. Clinical deterioration was defined as a change in New York Heart Association (NYHA) class from I/II to III/IV in the context of worsening left ventricular function in the six months before diagnosis. Radiological evidence of pulmonary venous hypertension was defined as an upper lobe pulmonary venous diameter $>15 \mathrm{~mm}$. In 71 patients (64\%) maximal symptom-limited exercise testing was performed upright on a treadmill with continuous measurement of oxygen consumption (Marquette MG 1100), using a Bruce or modified Bruce protocol. Before they were studied patients practised the techniques of metabolic exercise testing and had demonstrated consistent maximal oxygen consumption $\left(\mathrm{Vo}_{2} \mathrm{max}\right)$ data (less than $10 \%$ variation) on at least two consecutive exercise studies. Measured $\mathrm{Vo}_{2} \max$ was expressed as percentage of the age, gender, and body surface area predicted value $\left(\mathrm{VO}_{2} \%\right)$ using standard formulae. ${ }^{18}$ All patients over the age of 40 had selective coronary angiography, left ventriculography, and right ventricular endomyocardial biopsy; this applied to 101 of the 110 patients $(92 \%)$. The normal mean (SD) value for angiographic left ventricular ejection fraction in our laboratory is 70 (5)\%; measurements of ejection fraction $\leqslant 50 \%$ (outside three standard deviations from normal) were considered abnormal. The nine patients under the age of 40 had no chest pain, no risk factors for coronary artery disease, and no electrocardiographic evidence of exertional ischaemia. Histological diagnosis was obtained by light microscopy..$^{19}$ At follow up all 110 patients underwent clinical assessment and 12 lead electrocardiography; echocardiography was performed in 80 patients and metabolic exercise stress testing in 59.

\section{IMMUNOLOGICAL METHODS \\ Cardiac antibody testing by indirect \\ immunofluorescence}

Serum from $2 \mathrm{ml}$ of blood, obtained at the time of routine laboratory tests, was used. Serum samples were tested at $1 / 10$ dilution on $4 \mu \mathrm{m}$ unfixed fresh frozen cryostat sections of blood group $O$ normal human atrium and skeletal muscle. ${ }^{813}$ Cardiac antibody titres were measured by doubling dilutions of sera in phosphate buffered solution (PBS). Antibody patterns were classified as reported. ${ }^{813}$ Briefly, “organ-specific" antibodies produced a diffuse cytoplasmic staining of myocytes; "cross-reactive 1" antibodies gave a fine striational immunofluorescence on cardiac tissue but stained skeletal muscle fibres only weakly; "cross-reactive 2" antibodies stained with a broad striational pattern both heart and skeletal muscle sections. Absorption studies with relevant tissues had confirmed the organ-specificity and cross-reactivity of the three antibody types. ${ }^{8}$ Antibodies of the cross-reactive 2 type are found in a small proportion of dilated cardiomyopathy cases and controls ${ }^{8}$; this finding also applied to the present study and these results are not detailed. Two sera were used as standard positive (antibody titre 1/40) and negative controls and titrated in every assay. The intensity of immunofluorescence of the positive standard at 1/40 dilution was used as the threshold for positivity. All sera tested at $1 / 10$ dilution were read blindly against these standards. An additional positive control serum was titrated to assess reproducibility. ${ }^{8}$ End point titres for this serum were reproducible within one double dilution in all assays.

\section{Disease and normal controls for the immunofluorescence test}

Control groups for the immunofluorescence test included 301 patients (mean (SD) age 48 (11) years, 205 male) with cardiac disease other than dilated cardiomyopathy, of whom 141 had ischaemic heart failure (mean (SD) angiographic ejection fraction $=30(8) \%)$, and 160 had miscellaneous diseases (55 rheumatic heart disease, 67 hypertrophic cardiomyopathy, 38 congenital heart defects), and 200 healthy blood donors (age 35 (11) years, 91 male). All 200 controls and 225 of the 301 disease controls had been assessed for their antibody status and their features reported elsewhere. ${ }^{8}$

\section{Anti- $\alpha$ myosin antibody testing by immunosorbent assay method}

Atrial tissue, obtained from one normal donor heart at the time of transplantation, was frozen in liquid nitrogen and stored at $-80^{\circ} \mathrm{C}$ until use. The $\alpha$-(atrial specific) myosin samples were prepared as described. ${ }^{10}$ The ELISA method for detection of anti- $\alpha$ myosin antibodies has been reported before. ${ }^{12}$ Briefly, ELISA plates (Immulon 1; Dynatech, W Sussex) were coated with sequential duplicates of $100 \mu \mathrm{l}$ purified human $\alpha$-myosin at a concentration of $5 \mu \mathrm{g} / \mathrm{ml}$. Sera were diluted at $1 / 320$ in PBS (Sigma, UK) containing $0.1 \%$ Tween 20 and $1 \%$ bovine serum albumin. Absorbance was assessed using a Pasteur Diagnostics ELISA reader at $450 \mathrm{~nm}$. All antibody titres are expressed as mean (SEM) absorbance at $450 \mathrm{~nm}$. The upper limit of normal for the assay was defined as $2 \mathrm{SD}$ above the mean value obtained from the healthy controls.

\section{Ischaemic and healthy control subjects for the immunosorbent assay.}

The ELISA control groups included 203 healthy individuals (age 45 (16) years, 100 
Table 1 Baseline clinical and diagnostic features of the 110 study patients with dilated cardiomyopathy

\begin{tabular}{ll}
\hline Variable & Value \\
\hline Age (y) & $44(13)$ \\
No (\%) of men & $85(77 \%)$ \\
New York Heart Association class: & \\
I & $47(43 \%)$ \\
II & $23(21 \%)$ \\
III & $30(27 \%)$ \\
IV & $10(9 \%)$ \\
Syncope & $7(7 \%)$ \\
Palpitation & $27(25 \%)$ \\
Chest pain & $22(20 \%)$ \\
Thromboembolism & $2(2 \%)$ \\
Clinical deterioration & $60(55 \%)$ \\
Pulmonary venous hypertension on chest x ray & $74(67 \%)$ \\
Sinus rhythm & $81(74 \%)$ \\
Established atrial fibrillation & $24(22 \%)$ \\
Left bundle branch block & $30(27 \%)$ \\
Ventricular ectopic beats $(>10$ per hour) & $63(76 \%)$ \\
Non-sustained ventricular tachycardia & $48(58 \%)$ \\
Echocardiography: & \\
Left atrial dimension (mm) & $44(8)$ \\
Left ventricular end-diastolic dimension $(\mathrm{mm})$ & $68(11)$ \\
Left ventricular end-systolic dimension $(\mathrm{mm})$ & $59(12)$ \\
Fractional shortening (\%) & $14(7)($ range 2-24) \\
Maximal oxygen consumption $\left(\right.$ Vo ${ }_{2}$ max) $(\mathrm{ml} / \mathrm{kg} / \mathrm{min})$ & $22(10)$ \\
Vo & $57(25)($ range 5-115) \\
Angiographic left ventricular ejection fraction $(\%)$ & $26(10)($ range 5-50) \\
\hline Valus in parentheses are SD unless indicated &
\end{tabular}

Values in parentheses are SD unless indicated otherwise.
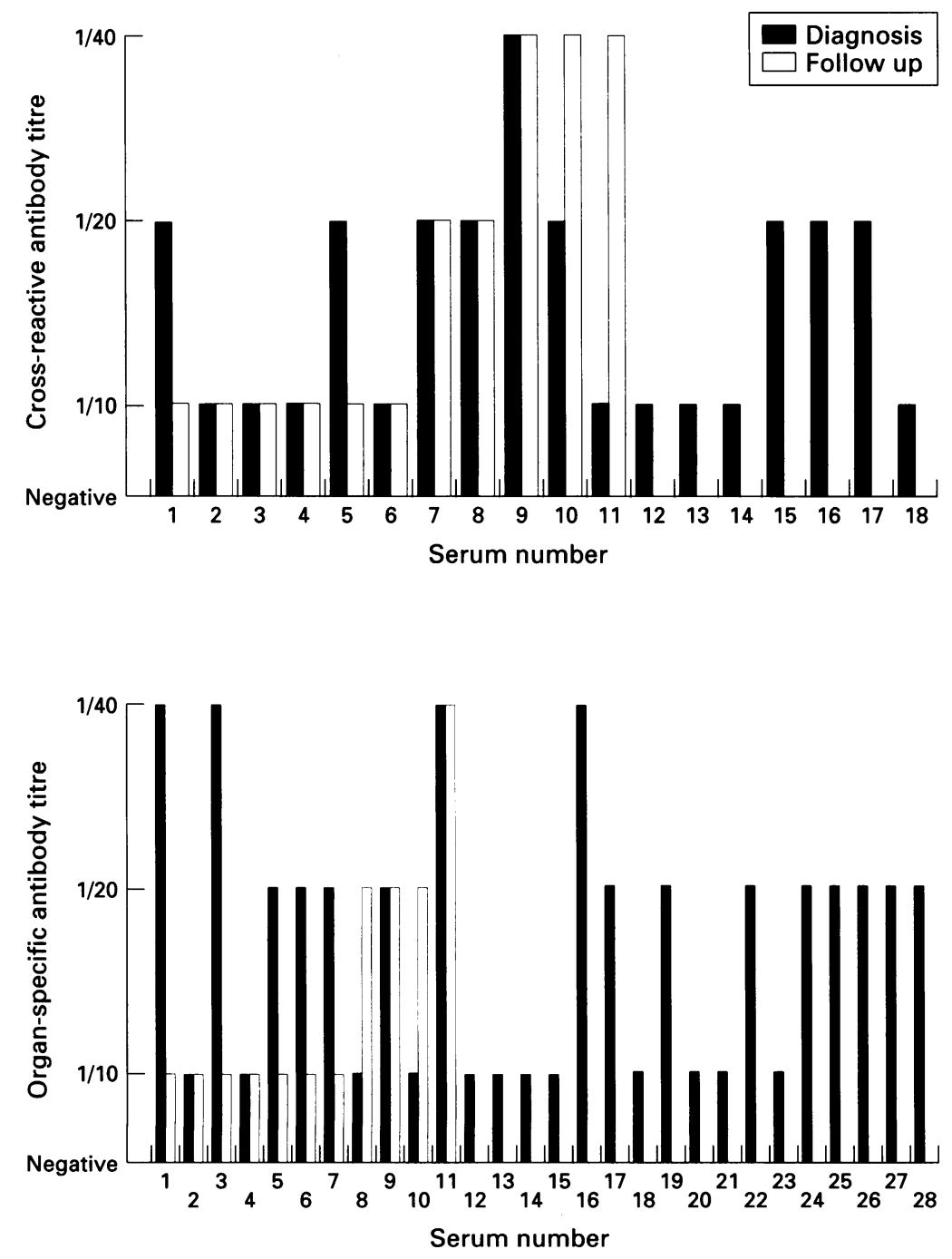

Immunofluorescence titres at diagnosis (solid bars) and at follow up (white bars) in the 46 patients who were antibody positive at diagnosis. Patients with antibodies of the crossreactive 1 type are shown in the top graph $(n=18)$ and those with antibodies of the organ-specific type are shown in the bottom graph $(n=28)$. Patients 12 to 18 (top) and 12 to 28 (bottom) became antibody negative at follow up. male) with normal clinical and non-invasive cardiac assessment and 92 patients with coronary artery disease (age 63 (11), 65 male). ${ }^{12}$

\section{STATISTICAL ANALYSIS}

Results for quantitative features are given as means (SD). Student's $t$ test, one-way analysis of variance, a chi-squared test, or Fisher's exact test were used as appropriate. All $P$ values were two-tailed; $P$ values below 0.05 were considered to indicate statistical significance.

\section{Results}

CLINICAL AND DIAGNOSTIC FEATURES OF PATIENTS WITH DILATED CARDIOMYOPATHY Baseline features at presentation in the 110 patients are summarised in table 1. Patients had been symptomatic for 29 (39) months (range 0 to 204$) ; 77(70 \%)$ were referred for management of heart failure, 17 (15\%) for specific arrhythmias, $16(14 \%)$ for transplant assessment; 60 (55\%) were deteriorating clinically. All patients had increased left atrial and ventricular echocardiographic dimensions and reduced fractional shortening (mean (SD) 14 (7)). Vo2max expressed as percentage of age, gender, and body surface area predicted value was reduced in all but one patient, who had normal functional capacity $(115 \%)$ but reduced left ventricular systolic function both on echocardiography (fractional shortening = $24 \%$ ) and angiography (ejection fraction = $32 \%)$. Angiographic left ventricular percentage ejection fraction was markedly reduced (mean (SD) 26 (10)) in all but one patient, who had a percentage ejection fraction of 50 . Abnormal endomyocardial biopsy features including mild interstitial fibrosis, myocyte hypertrophy and/or nuclear changes were found in $58 \%$ of the patients; the remainder had entirely normal findings. All patients were treated with diuretics and vasodilator drugs: $33(30 \%)$ with an anticoagulant; $31(23 \%)$ with amiodarone; 25 (23\%) with digoxin, 24 of whom were in established atrial fibrillation.

At follow up $52(47 \%)$ of the 110 patients were in NYHA class I, $23(21 \%)$ in II, 31 $(28 \%)$ in III, and four (4\%) in IV. Mean (SD) echocardiographic percentage fractional shortening was 19 (9), $\mathrm{VO}_{2} \max$ was 24 (9) $\mathrm{ml} / \mathrm{kg} / \mathrm{min}$, and $\mathrm{Vo}_{2} \%$ was 64 (23), range 5 to 115).

\section{CARDIAC ANTIBODIES BY}

IMMUNOFLUORESCENCE: FREQUENCY AT DIAGNOSIS AND FOLLOW UP IN DILATED CARDIOMYOPATHY

At diagnosis, cardiac autoantibodies of the organ-specific type were more frequently detected in dilated cardiomyopathy $(28 / 110$, $25 \%)$ than in other cardiac disease $(1 / 160$, $1 \%, P=0.0001$ ), in ischaemic heart failure $(1 / 141,1 \%, P=0.0001)$, or in healthy controls $(7 / 200,3 \%, P=0.0001)$. Cardiac autoantibodies of the cross-reactive 1 type were also more common in dilated cardiomyopathy $(18 / 110,16 \%)$ than in other cardiac disease $(7 / 160,4 \%, \quad P=0.0008), \quad$ in ischaemic heart failure $(1 / 141,1 \%, P=$ 
Table 2 Relation between immunofluorescence result at diagnosis and features at diagnosis in dilated cardiomyopathy (mean (SD))

\begin{tabular}{|c|c|c|c|c|}
\hline \multirow[b]{2}{*}{ Features at diagnosis } & \multicolumn{3}{|c|}{ Antibody $(A b)$ result at diagnosis } & \multirow[b]{2}{*}{$P$} \\
\hline & $\begin{array}{l}\text { O-s Ab } \\
\text { positive } \\
(n=28)\end{array}$ & $\begin{array}{l}\text { Cross- } R A b \\
\text { positive } \\
(n=18)\end{array}$ & $\begin{array}{l}A b \\
\text { negative } \\
(n=64)\end{array}$ & \\
\hline $\begin{array}{l}\text { Age at diagnosis (y) } \\
\text { Symptom duration (mnth) } \\
\text { Number }(\%) \text { NYHA I-II } \\
\text { Number }(\%) \text { of patients with }\end{array}$ & $\begin{array}{l}42(15) \\
24(29) \\
20(71 \%)\end{array}$ & $\begin{array}{l}47(14) \\
35(40) \\
9(50 \%)\end{array}$ & $\begin{array}{l}44(12) \\
30(43) \\
40(62 \%)\end{array}$ & $\begin{array}{l}\text { NS } \\
\text { NS } \\
\text { NS }\end{array}$ \\
\hline $\begin{array}{l}\text { clinical deterioration } \\
\text { LVEDD }(\mathrm{mm}) \\
\text { LVESD }(\mathrm{mm}) \\
\text { FS }(\%) \\
\text { Angiographic EF (\%) } \\
\text { PCWP (mm Hg) }\end{array}$ & $\begin{array}{l}13(46 \%) \\
68(8) \\
58(10) \\
15(7) \\
25(11) \\
21(8)\end{array}$ & $\begin{array}{l}12(67 \%) \\
71(11) \\
61(13) \\
13(7) \\
25(11) \\
24(8)\end{array}$ & $\begin{array}{l}35(55 \%) \\
68(12) \\
59(13) \\
14(8) \\
27(10) \\
19(10)\end{array}$ & $\begin{array}{l}\text { NS } \\
\text { NS } \\
\text { NS } \\
\text { NS } \\
\text { NS }\end{array}$ \\
\hline $\begin{array}{l}\mathrm{Vo}_{2} \max (\mathrm{ml} / \mathrm{min} / \mathrm{kg}) \\
\mathrm{Vo}_{2} \%\end{array}$ & $\begin{array}{l}(n=16) \\
25(7) \\
71(18)\end{array}$ & $\begin{array}{l}(n=14) \\
22(12) \\
60(27)\end{array}$ & $\begin{array}{l}(n=41) \\
20(10) \\
51(25)\end{array}$ & $\begin{array}{l}\text { NS } \\
0.017\end{array}$ \\
\hline
\end{tabular}

FS, fractional shortening; LVEDD, left ventricular end diastolic dimension; LVESD, LV end systolic dimension; NYHA, New York Heart Association; O-s, organ-specific; cross-R, crossreactive; PCWP, mean pulmonary capillary wedge pressure; $\mathrm{EF}$, ejection fraction; $\mathrm{VO}_{2} \mathrm{max}$ maximal oxygen consumption; $\mathrm{VO}_{2} \%, \mathrm{VO}_{2}$ max expressed as $\%$ of the predicted value

Table 3 Relations between immunofluorescence and immunosorbent assay results at diagnosis and features at follow up in dilated cardiomyopathy

\begin{tabular}{|c|c|c|c|c|}
\hline \multirow[b]{2}{*}{ Features at follow up } & \multicolumn{3}{|c|}{ Antibody $(A b)$ result at diagnosis } & \multirow[b]{2}{*}{$P$} \\
\hline & $\begin{array}{l}O-s A b \\
\text { positive }\end{array}$ & $\begin{array}{l}\text { Cross- } R A b \\
\text { positive }\end{array}$ & $\begin{array}{l}A b \\
\text { negative }\end{array}$ & \\
\hline Number (\%) NYHA I-II & $\begin{array}{l}(n=28) \\
25(89 \%)\end{array}$ & $\begin{array}{l}(n=18) \\
10(55 \%)\end{array}$ & $\begin{array}{l}(n=64) \\
40(62 \%)\end{array}$ & 0.02 \\
\hline FS (\%) & $\begin{array}{l}(n=24) \\
20(9)\end{array}$ & $\begin{array}{l}(n=14) \\
15(9)\end{array}$ & $\begin{array}{l}(n=42) \\
21(10)\end{array}$ & NS \\
\hline $\begin{array}{l}\mathrm{Vo}_{2} \max (\mathrm{ml} / \mathrm{min} / \mathrm{kg}) \\
\mathrm{Vo}_{2} \%\end{array}$ & $\begin{array}{l}(n=17) \\
24(9) \\
69(18)\end{array}$ & $\begin{array}{l}(n=12) \\
21(10) \\
58(19)\end{array}$ & $\begin{array}{l}(n=30) \\
25(9) \\
64(28)\end{array}$ & $\begin{array}{l}\text { NS } \\
\text { NS }\end{array}$ \\
\hline Number (\%) NYHA I-II & $\begin{array}{l}\text { Abnormal } \\
(n=14) \\
10(71 \%)\end{array}$ & & $\begin{array}{l}\text { Normal ELISA } \\
(n=43) \\
35(81 \%)\end{array}$ & NS \\
\hline FS (\%) & $\begin{array}{l}(n=10) \\
23(8)\end{array}$ & & $\begin{array}{l}(n=31) \\
20(11)\end{array}$ & NS \\
\hline $\begin{array}{l}\mathrm{Vo}_{2} \max (\mathrm{ml} / \mathrm{min} / \mathrm{kg}) \\
\mathrm{Vo}_{2} \%\end{array}$ & $\begin{array}{l}(n=9) \\
26(7) \\
79(17)\end{array}$ & & $\begin{array}{l}(n=39) \\
23(9) \\
60(24)\end{array}$ & $\begin{array}{l}\text { NS } \\
0.03\end{array}$ \\
\hline
\end{tabular}

FS, fractional shortening; LVEDD, left ventricular end diastolic dimension; LVESD, LV end systolic dimension; NYHA, New York Heart Association; O-s, organ-specific; cross-R, crossreactive; PCWP, mean pulmonary capillary wedge pressure; $\mathrm{EF}$, ejection fraction; $\mathrm{VO}_{2} \mathrm{max}$, maximal oxygen consumption; $\mathrm{VO}_{2} \%, \mathrm{VO}_{2}$ max expressed as $\%$ of the predicted value.

Table 4 Relation between antibody persistence at follow up by immunofluorescence and features at diagnosis in dilated cardiomyopathy

\begin{tabular}{|c|c|c|c|c|}
\hline \multirow[b]{3}{*}{ Features at diagnosis } & \multicolumn{3}{|c|}{ Antibody result at follow up } & \multirow[b]{3}{*}{$P$} \\
\hline & \multicolumn{2}{|c|}{ Persistent $A b$} & \multirow{2}{*}{$\begin{array}{l}\text { Lost } A b \\
\text { Ab } \\
\text { negative } \\
(n=24)\end{array}$} & \\
\hline & $\begin{array}{l}O-s A b \\
\text { positive } \\
(n=11)\end{array}$ & $\begin{array}{l}\text { Cross-R Ab } \\
\text { positive } \\
(n=11)\end{array}$ & & \\
\hline $\begin{array}{l}\text { Age at diagnosis (y) } \\
\text { Symptom duration (mnth) } \\
\text { Number (\%) NYHA I-II } \\
\text { Number (\%) of patients with }\end{array}$ & $\begin{array}{l}42(16) \\
28(35) \\
10(91 \%)\end{array}$ & $\begin{array}{l}47(12) \\
22(25) \\
8(73 \%)\end{array}$ & $\begin{array}{l}43(15) \\
32(38) \\
12(50 \%)\end{array}$ & $\begin{array}{l}\text { NS } \\
\text { NS } \\
0 \cdot 05 t^{\star}\end{array}$ \\
\hline $\begin{array}{l}\text { clinical deterioration: } \\
\text { LVEDD (mm) } \\
\text { LVESD (mm) } \\
\text { FS (\%) } \\
\text { Angiographic EF (\%) } \\
\text { PCWP (mm Hg) }\end{array}$ & $\begin{array}{l}2(18 \%) \\
70(9) \\
59(13) \\
17(9) \\
25(11) \\
21(8)\end{array}$ & $\begin{array}{l}6(54 \%) \\
69(6) \\
59(9) \\
14(7) \\
24(11) \\
26(8)\end{array}$ & $\begin{array}{l}17(71 \%) \\
68(11) \\
60(12) \\
13(6) \\
28(10) \\
21(7)\end{array}$ & $\begin{array}{l}0.01 \ddagger \\
\text { NS } \\
\text { NS } \\
\text { NS } \\
\text { NS } \\
\text { NS }\end{array}$ \\
\hline $\begin{array}{l}\mathrm{Vo}_{2} \max (\mathrm{ml} / \mathrm{min} / \mathrm{kg}) \\
\mathrm{VO}_{2} \%\end{array}$ & $\begin{array}{l}(n=3) \\
26(3) \\
64(8)\end{array}$ & $\begin{array}{l}(n=7) \\
25(7) \\
73(14)\end{array}$ & $\begin{array}{l}(n=20) \\
23(11) \\
64(27)\end{array}$ & $\begin{array}{l}\text { NS } \\
\text { NS }\end{array}$ \\
\hline
\end{tabular}

Values are means (SD). Persistent $\mathrm{Ab} v$ lost $\mathrm{Ab}$ : ${ }^{\star} \mathrm{P}=\mathrm{NS}(0.05)$; $\mathrm{O}-\mathrm{s} v$ non $\mathrm{O}-\mathrm{s}: \nmid \mathrm{P}=0.04, \ddagger \mathrm{P}$ $=0.005 ; \mathrm{O}-\mathrm{s} v \mathrm{Ab}$ negative: $+\mathrm{P}=0.02, \ddagger \mathrm{P}=0.004$.

$0.0001)$, or in healthy controls $(5 / 200,2 \%$, $\mathbf{P}=0.0001)$. Cardiac antibody titres in the patients with dilated cardiomyopathy were as follows: $1 / 10$ in 21 sera $(19 \%), 1 / 20$ in 20 $(18 \%)$, and $1 / 40$ in five $(4 \cdot 5 \%)$. All positive sera contained autoantibodies of the IgG class.
At follow up cardiac autoantibodies of the IgG class were detected in 22 patients with dilated cardiomyopathy; 11 of them (10\%) had autoantibodies of the organ-specific and $11(10 \%)$ of the cross-reactive 1 type. Cardiac antibody titres were $1 / 10$ in 13 sera $(12 \%)$, $1 / 20$ in five $(4.5 \%)$, and $1 / 40$ in four $(4 \%)$. Autoantibodies of both the organ specific and of the cross reactive 1 types were significantly less common at follow up than at diagnosis $(11(10 \%) v 28(25 \%)$ and $11(10 \%) v 18$ (16\%) respectively; $P=0.002)$. Antibody titres at diagnosis and follow up in the 46 patients found to be positive at diagnosis are shown in the figure. Of these 46 patients, 22 $(48 \%)$ were persistently antibody positive and $24(52 \%)$ became negative at follow up, but none of the 64 patients who were negative at diagnosis became positive at follow up ( $P=$ 0.0001).

ANTI- $\alpha$ MYOSIN ANTIBODIES BY

IMMUNOSORBENT ASSAY: FREQUENCY AT DIAGNOSIS AND FOLLOW UP IN DILATED CARDIOMYOPATHY

At diagnosis mean (SEM) anti- $\alpha$ myosin antibody titres were higher in dilated cardiomyopathy $(0.30(0.02))$ than in ischaemic $(0.19$ $(0.01) ; \mathrm{P}=0.001)$ or healthy controls $(0.17$ $(0.01) ; P=0.0001)$; there was no difference between ischaemic and healthy controls $(0 \cdot 19$ $(0.01) v 0.17(0.01) ; \mathrm{P}=\mathrm{NS})$. A greater proportion of the patients with dilated cardiomyopathy $(14 / 57,24 \%)$ had abnormally raised antibody titres compared with ischaemic $(4 / 92,4 \%)$ or healthy controls $(4 / 203,2 \%$; P $=0.0001)$. At follow up mean antibody titres in dilated cardiomyopathy were significantly lower than at diagnosis $(0.24(0.02) v 0.30$ $(0.02) ; P=0.038)$; abnormal results were found in $8 / 57$ patients $(14 \%)$. Of the 14 patients with abnormal results at diagnosis, eight $(57 \%)$ were persistently abnormal and six $(43 \%)$ became normal at follow up, but none of the 43 patients with normal results at diagnosis became abnormal at follow up ( $\mathrm{P}=$ 0.0001 ).

RELATIONS BETWEEN ANTIBODY RESULTS AT DIAGNOSIS AND FEATURES AT DIAGNOSIS AND AT FOLLOW UP IN DILATED CARDIOMYOPATHY Associations between immunofluorescence results at diagnosis and features at diagnosis are shown in table 2. Dilated cardiomyopathy cases with organ-specific cardiac antibody had greater $\mathrm{Vo}_{2} \%(71$ (18)) than those with crossreactive antibody $(60(27))$ or antibody negative patients (51 (25), $P=0.017$ ). Mean $\mathrm{VO}_{2} \%$ was greater $(\mathrm{P}=0.03)$ in patients with higher titres (1/40) of antibody: 51 (25) in antibody negative patients, 68 (26) in patients with $1 / 10$ antibody titre, 59 (19) in patients with titre $1 / 20$, and $82(16)$ in those with titre $1 / 40$. Mean symptom duration (months) tended to be shorter $(P=N S)$ in patients with higher antibody titres (1/40): 30 (42) in antibody negative patients, 37 (40) in patients with $1 / 10$ antibody titre, 25 (28) in patients with titre $1 / 20$, and $4(5)$ in those with titre $1 / 40$. There were no significant associations 
between other clinical, haemodynamic, or echocardiographic features at diagnosis and antibody results at diagnosis by immunofluorescence (table 2) or ELISA (results not shown).

Associations between antibody status at diagnosis and features at follow up are shown in table 3. The proportion of dilated cardiomyopathy cases with milder symptoms (NYHA I-II) at follow up was higher among those with organ-specific cardiac antibody at diagnosis $(25,89 \%)$ than among those with cross-reactive antibody $(10,55 \%)$ or among antibody negative patients $(40,62 \%, \mathrm{P}=$ $0.02) . \mathrm{VO}_{2} \%$ at follow up was significantly higher in patients with abnormally raised anti- $\alpha$ myosin antibody titres than in those with normal ELISA results $(79$ (17) $v 60$ (24)\%, $\mathrm{P}=$ $0.03)$.

\section{ANTIBODY PERSISTENCE AT FOLLOW UP AND} FEATURES AT DIAGNOSIS AND AT FOLLOW UP When features at diagnosis in patients with dilated cardiomyopathy who had persistent antibodies by immunofluorescence at follow up $(\mathrm{n}=22)$ were compared with those who were positive at diagnosis and became negative at follow up ( $n=24)$ we found that milder symptoms (NYHA I-II) were more common among the patients with persistent organ-specific cardiac antibody $(10,91 \%)$ than among those without $(20,57 \%, \mathrm{P}=0.04)$ or among antibody negative patients $(12,50 \%, P=$ 0.02 ) (table 4). Fewer patients with persistent organ-specific cardiac antibody were clinically deteriorating $(2,18 \%)$ than those without $(23$, $66 \%, P=0.005)$ or than antibody negative patients $(17,71 \%, P=0.004)$. No other significant associations were found between ELISA results at follow up and features at diagnosis, or between antibody results (immunofluorescence or ELISA) at follow up and features at follow up (not shown).

\section{Discussion}

Using standardised techniques we found cardiac specific autoantibodies in $25 \%$ of patients with dilated cardiomyopathy at diagnosis and a decline in titres over time with antibody persistence in only half of the patients at one year follow up. These antibodies were uncommon in controls; this is in keeping with the findings in other autoimmune diseases ${ }^{15} 16^{20-22}$ and confirms our previous observations in distinct patient series. ${ }^{82-24}$ The concordance between immunofluorescence and ELISA is not surprising; although the two techniques have different cut-offs, in the ELISA we used $\alpha$-myosin, which is one of the autoantigens recognised by the antibodies detected by immunofluorescence. ${ }^{10}$

Decline of autoantibody titres with disease evolution is a recognised feature of other autoimmune disorders-for example, longstanding type 1 diabetes. ${ }^{1516}$ Thus the reduction in autoantibody production as heart failure progresses in dilated cardiomyopathy is not an unexpected finding. Although immunofluorescence is only semiquantitative, we used a standardised technique that in our experience is reliable and highly reproducible. ${ }^{813}$ Similar results have been achieved for detection of other organ-specific autoantibodies, for which immunofluorescence represents the gold standard technique. ${ }^{20}$ Furthermore, the reduction of autoantibody titres at follow up was confirmed by quantitative ELISA. Some previous workers reported that heart failure patients, regardless of the aetiology of heart dysfunction, may have a high frequency of circulating cardiac autoantibodies; such studies have not systematically standardised techniques, and did not document the distinction between organ-specific and skeletal muscle cross-reactive autoantibodies. ${ }^{725-28}$ These factors may enhance the rate of false-positive results. ${ }^{8}$

Another finding presented here was that the detection of cardiac specific autoantibodies at diagnosis was associated with greater exercise tolerance, expressed by objective measurement of exercise capacity. ${ }^{18}{ }^{29}$ In fact antibody positive patients had greater $\mathrm{Vo}_{2} \%$ both at diagnosis or at one year follow up than those who were antibody negative; in addition $\mathrm{Vo}_{2} \%$ was positively related to a high antibody titre. These data strongly suggest that cardiac antibodies are early markers. The fact that mean symptom duration before diagnosis correlated poorly with antibody status is not surprising; assessment of symptoms is inferior to objective $\mathrm{Vo}_{2}$ max measurements of functional capacity in evaluating disease evolution in heart failure patients. ${ }^{29-30}$ In addition, patients with dilated cardiomyopathy may be symptom-free or for long periods may experience few symptoms; this may also explain a relatively poor correlation at diagnosis between antibody status and symptom duration. Nevertheless, when patients who had persistently detectable antibodies at follow up were compared with those who had lost these markers, persistence of cardiac specific antibodies was associated with milder symptoms at presentation and with absence of clinical deterioration. Positive antibody status at diagnosis was also associated with milder symptoms and greater $\mathrm{Vo}_{2} \%$ at follow up. These findings again suggest that the antibody markers are associated with early disease. In keeping with this view is the detection of the same antibodies in symptom-free relatives of patients with dilated cardiomyopathy; these relatives had borderline left ventricular dysfunction on echocardiography. ${ }^{13}$

In conclusion, the follow up data presented in this study indicate that cardiac-specific autoantibodies in dilated cardiomyopathy become undetectable with disease progression. Patients may go through a pre-clinical period when autoantibody titres are high, but heart dysfunction is unrecognised. It is important to screen and follow up their symptom-free relatives to identify those at risk, to achieve early diagnosis and potential preventative therapeutic measures. In documented dilated cardiomyopathy, presence of antibody at diagnosis was associated with milder symptoms and greater functional capacity one year later, and antibody persistence at one year follow up was associated with stable disease and milder 
symptoms at diagnosis. This may provide a non-invasive adjunctive marker for patients at early disease stages, although extended longitudinal observations are needed to firmly establish the role of the antibody as a prognostic marker.

ALPC was supported by grants from the Veneto Region Target Project on Cardiomyopathies and the National Research Project on Cardiomyopathies and the National Research Council target project FAT.MA (Rome, Italy). PJK, JHG, and
MKB were supported by grants from the British Heart Foundation.

1 Brandenburg RO, Chazov E, Cherian G, Falase AO Grosgogeat Y, Kawai C, et al. Report of the WHO/ISFC task force on definition and classification of the cardiomyopathies. Circulation 1981;64:437A-8A.

2 Manolio TA, Baughman KL, Rodeheffer R, Pearson TA Bristow D, Michels VV, et al. Prevalence and etiology of idiopathic dilated cardiomyopathy (summary of a National Heart, Lung, and Blood Institute workshop). Am f Cardiol 1992;69:1458-66.

3 Limas CJ, Goldenberg IF, Limas C. Autoantibodies against $\beta$-adrenoceptors in human idiopathic dilated car-

4 Magnusson Y, Marullo S, Hoyer S, Waagstein F Andersson B, Vahlne A, et al. Mapping of a functiona autoimmune epitope on the $\beta_{1}$ adrenergic receptor in patients with idiopathic dilated cardiomyopathy. $\mathscr{F}$ Clin Invest 1990;86:1658-63.

5 Klein R, Maisch B, Kochsiek K, Berg PA. Demonstration of organ-specific antibodies against heart mitochondria (anti-M7) in sera from patients with some forms of heart diseases. Clin Exp Immunol 1984;58:283-92.

6 Schultheiss HP, Bolte HD. Immunological analysis of auto-antibodies against the adenine nucleotide translocator in dilated cardiomyopathy. $\mathcal{F} \mathrm{Mol}$ Cell Cardiol 1985; tor in dilated

7 Maisch B, Deeg P, Liebau G, Kochsiek K. Diagnostic relevance of humoral and cytotoxic immune reactions in primary and secondary dilated cardiomyopathy. $\mathrm{Am} \mathcal{F}$ Cardiol 1983;52: 1072-8.

8 Caforio ALP, Bonifacio E, Stewart JT, Neglia D, Parodi O, Bottazzo GF, et al. Novel organ-specific cardiac autoantibodies in dilated cardiomyopathy. $7 \mathrm{Am}$ Coll Cardiol 1990;15:1527-34.

9 Neumann DA, Burek CL, Baughman KL, Rose NR, Herskowitz A. Circulating heart-reactive antibodies in patients with myocarditis or cardiomyopathy. $₹ \mathrm{Am}$ Coll Cardiol 1990;16:839-46.

10 Caforio ALP, Grazzini M, Mann JM, Keeling PJ, Bottazzo GF, McKenna WJ, et al. Identification of the $\alpha$ and $\beta$ myosin heavy chain isoforms as major autoantigens in dilated cardiomyopathy. Circulation 1992;85:1734-42.

11 Latif N, Baker CS, Dunn MJ, Rose ML, Brady P, Yacoub MH. Frequency and specificity of antiheart antibodies in patients with dilated cardiomyopathy detected using 1993;22:1378-84.

12 Goldman JH, Keeling PJ, Warraich RS, Redwood S, Baig $\mathrm{KM}$, Elliott PM, et al. Autoimmunity to $\alpha$-myosin in a subset of patients with idiopathic dilated cardiomyopathy. Br Heart f 1995;74:598-603.

13 Caforio ALP, Keeling PJ, Zachara E, Mestroni L, Camerini
F, Mann JM, et al. Autoimmunity in dilated cardiomyopathy: evidence from family studies. Lancet 1994;344: opathy:

14 Caforio ALP. Role of autoimmunity in dilated cardiomyopathy. Br Heart f 1994;72 (suppl):S30-4.

15 Bottazzo GF, Dean BM, Gorsuch AN, Cudworth AG, Doniach D. Complement-fixing islet-cell antibodies in Type-I diabetes: possible monitors of active $\beta$-cell damage. Lancet 1980;i:668-72.

16 Bottazzo GF. On the honey disease. A dialogue with Socrates. Diabetes 1993;42:778-800.

17 Fuster V, Gersh BJ, Giuliani ER, Tajik AJ, Brandenburg AO, Frye RL. The natural history of idiopathic dilated cardiomyopathy. Am $¥$ Cardiol 1981;47:525-31.

18 Blackie SP, Fairbarn MS, MCelvaney GN, Morrison NJ, Wilcox PG, Pardy RL. Prediction of maximal oxygen uptake and power during cycle ergometry in subjects older than 55 years of age. Am Rev Respir Dis 1989;139: $1424-9$.

19 Aretz HT, Billingham ME, Edwards WE, Factor S, Fallon J, Fenoglio J Jr, et al. Myocarditis: a histopathological definition and classification. Am f Cardiol Pathol 1985;1:1-10.

20 Bonifacio E, Bingley PJ, Shattock M, Dean BM, Dunger $\mathrm{D}$, Gale EA, et al. Quantitation of islet-cell antibodies and prediction of insulin-dependent diabetes. Lancet 1990;335:147-9.

21 Bottazzo GF, Todd I, Mirakian R, Belfiore A, Pujol-Borrell R. Organ-specific autoimmunity. A 1986 overview. Immunol Rev 1986;94:137-69.

22 Rose NR, Bona C. Defining criteria for autoimmune disease (Witebsky's postulates revisited). Immunol Today $1991 ; 14: 426-8$

23 Caforio ALP, Martinetti M, Bonifacio E, Gavazzi A, Graziano G, Cuccia MC, et al. Idiopathic dilated cardiomyopathy: lack of association between organ-specific cardiac antibodies and HLA-DR antigens. Tissue Antigens 1992;39:236-40.

24 Bilinska ZT, Caforio ALP, Grzybowski J, Michalak E, Kusmierczyc-Droszcz B, Goldman $\mathrm{JH}$, et al. Organ-spe-
cific cardiac autoantibodies in dilated cardiomyopathy: frequency and clinical correlates in Polish patients. Eur Heart $\mathcal{f} 1995 ; 16: 1907-11$.

25 Kaplan MH, Frengley DJ. Autoimmunity to the heart in cardiac disease. Current concepts of the relation of autoimmunity to rheumatic fever, post-cardiotomy and post infarction syndromes and cardiomyopathies. $\mathrm{Am} \mathcal{F}$ Cardiol 1969;24:459-73.

26 Maisch B, Berg PA, Kochsiek K. Clinical significance of immunopathological findings in patients with post-pericardiotomy syndrome. I Relevance of antibody pattern. Clin Exp Immunol 1979;38:189-97.

27 Lauer B, Padberg K, Schultheiss HP, Strauer BE. Autoantibodies against human ventricular myosin in sera of patients with acute and chronic myocarditis. $₹ \mathrm{Am}$ Coll of patients with acute and

28 De Scheerder IK, De Buyzere M, De Langhe J, Maas A, Clement DL, Wieme R. Humoral immune response against contractile proteins (actin and myosin) during cardiovascular disease. Eur Heart $\mathcal{F}$ 1991;12:88-94.

29 Frennaux MP, Counihan PJ, Caforio ALP, Chikamori T, McKenna WJ. Abnormal blood pressure response in hypertrophic cardiomyopathy. Circulation 1990;82: 1995-2002.

30 Mudge GH, Goldstein S, Addonizio LJ, Caplan A, Mancini D, Levine BT, et al. Task force 3: Recipient guidelines/prioritization. $\mathcal{F} \mathrm{Am}$ Coll Cardiol 1993;22: 21-30. 